This item was submitted to Loughborough's Research Repository by the author.

Items in Figshare are protected by copyright, with all rights reserved, unless otherwise indicated.

\title{
Older people and digital disengagement: a fourth digital divide?
}

PLEASE CITE THE PUBLISHED VERSION

http://dx.doi.org/10.1159/000353630

\section{PUBLISHER}

(c) S. Karger AG

\section{VERSION}

AM (Accepted Manuscript)

\section{PUBLISHER STATEMENT}

This work is made available according to the conditions of the Creative Commons Attribution-NonCommercialNoDerivatives 4.0 International (CC BY-NC-ND 4.0) licence. Full details of this licence are available at: https://creativecommons.org/licenses/by-nc-nd/4.0/ This work is made available according to the conditions of the Creative Commons Attribution-NonCommercial-NoDerivatives 4.0 International (CC BY-NC-ND 4.0) licence. Full details of this licence are available at: https://creativecommons.org/licenses/by-nc-nd/4.0/

\section{LICENCE}

CC BY-NC-ND 4.0

\section{REPOSITORY RECORD}

Olphert, Wendy, and Leela Damodaran. 2019. "Older People and Digital Disengagement: A Fourth Digital Divide?”. figshare. https://hdl.handle.net/2134/16953. 
Title: Older people and digital disengagement: a fourth digital divide?

Wendy Olphert and Leela Damodaran, Loughborough University

Key words: older people, ICT, digital technology, digital inclusion, digital divides, disengagement.

Department of Information Science, Bridgeman Building, Loughborough University, Loughborough, Leics LE11 3TU.

E: c.w.olphert@lboro.ac.uk; l.damodaran@lboro.ac.uk;

T: +44 (0)1509 225914

Short title for use as running head: Older people and digital disengagement 


\section{Abstract}

Digital technologies are becoming more pervasive in all areas of society. Enabling everyone to have access and capability to use the internet and associated digital technologies, summed up in the term 'digital inclusion', is seen to have wide-ranging benefits to the individual, to the economy and to society. For older people, being digitally included can help them to maintain their independence, social connectedness and sense of worth in the face of declining health or limited capabilities, as well as also offering new opportunities to improve their quality of life.

At present however access to the technology and to the benefits is not equally distributed either between or within nations, and older people tend to be on the 'wrong' side of what is termed the 'digital divide'. Governments globally are developing strategies to promote digital inclusion and indeed internet uptake is increasing steadily, including amongst older people. However, such strategies have focussed on getting people online, and there appears to be an assumption that once someone is online they will remain 'digitally engaged'. In fact statistics show that some users give up using the internet, and there is emerging evidence that older people are more vulnerable to the factors which can lead to this outcome. The authors see this phenomenon as a potential but largely unrecognised 'fourth digital divide' which has serious implications for social inclusion.

The objectives of this article are (i) to raise awareness of the phenomenon of digital disengagement by considering some of the emerging evidence, (ii) to explore some of the potential implications of not recognising and therefore not addressing the needs of the digitally disengaged older population, and (iii) to reveal the prevailing gap in knowledge which future research should address. 


\section{Introduction}

Digital technologies are becoming increasingly pervasive and integrated within society. Primarily through the medium of the internet, an ever-expanding range of information, goods, services, entertainment/leisure, educational and social networking opportunities are available. For those who choose and are able to access them, such opportunities can deliver a range of social and economic benefits and contribute to improved quality of life [1]. For providers, the internet is increasingly being seen as the most cost-effective way to market and deliver services to customers. In the context of global financial pressures, this applies to government as well as commercial service providers. In the UK for example, the government is pursuing a 'digital by default' strategy for the delivery of its planned Universal Credit benefit [2].

Older people represent a growing proportion of the world's population. By 2050, it is projected that a fifth (21\%) of the worldwide population) will be over 60 [3]. This demographic change over recent decades presents significant challenges for governments and society. Digital technologies and internet-based services are being seen as having a significant role to play in reducing the so-called 'burden of care' associated with an ageing population. In addition to specific telecare and telehealth initiatives [e.g. 4], access to the opportunities afforded by the internet in general is also important for older people. Studies suggest that, for older people, computers and the internet can become powerful assistive technologies, helping them to maintain their independence, social connectedness and sense of worth in the face of declining health or limited capabilities, as well as also offering new opportunities to improve their quality of life [5]. Conversely, older people, who are already a group at greater risk of exclusion in society through factors such as 
poverty, isolation and ill-health, face the possibility of new forms of social exclusion if they are unable to access the opportunities and services that are increasingly being delivered through the internet.

\section{Digital Engagement and Digital Divides}

To benefit from the opportunities offered through the internet requires older people to be 'digitally engaged'. However, statistics show that access to the internet is currently unevenly distributed amongst the global population, and older people in most countries are less likely to be internet users than younger people. Recent surveys $[6,7]$ report that while 80 per cent or more of the total population in Britain regularly use the internet, this drops to fewer than 40 per cent among people aged 50 and above. In some other countries the proportion of older internet users is much smaller - for example in Spain, where $67 \%$ of the total population are internet users, older users represent just $12 \%$ and in China only around $4 \%$ of older people are users, compared to around $40 \%$ of the population as a whole [8].

The gap between those who do and who do not enjoy the benefits of access to the internet has been termed the 'digital divide'1. Many studies have sought to explore the factors that underlie this phenomenon. These have demonstrated that the digital divide is not a simple binary division between the 'haves' and 'have-nots' [9] but that digital divides arise from three main sources of inequality which occur both between nations and within them. In simple terms these differences can be categorised as those of connectivity, capability, and content [10]. Thus, digital divides are likely to exist where people do not have i) access to appropriate equipment (connectivity), ii)

\footnotetext{
${ }^{1}$ The term is believed to have been first used in the U.S. during the Clinton administration
} 
appropriate skills and capabilities, and iii) motivation from the 'pull' of compelling functionality and content.

The large divide between older and younger people in terms of internet usage is explained partly because older people may not have the financial means to pay for equipment and services, partly because they may not have acquired the necessary skills either through education or in the workplace, and partly because they may not have any motivation or interest to use these new technologies. Chronological age however is clearly not a factor in itself, since many older people do use, and enjoy using, computers and the internet [11].

Numerous studies have confirmed these barriers to uptake of the internet, and this has led to the conclusion that non-users (the 'digitally unengaged') can be transformed into users (the 'digitally engaged') by an additive model which addresses each of the three types of barriers. Consequently, governments and other bodies in many countries are investing significant resources into providing technical infrastructure, awareness and training initiatives, and the development of digital content and digitally-delivered services, with the aim of increasing access to the internet and promoting digital engagement. (In terms of content, of course, there is a clear difference between content which is intrinsically compelling because an individual finds it interesting and rewarding - e.g. communicating with friends and family, or simply compelling because there may be little or no easily available alternative means of achieving a necessary goal).

In the UK, for example, the Government is simultaneously implementing strategies which address connectivity issues (with the aim of providing superfast broadband to at least 90 per cent of premises in the UK and to provide universal access to 
standard broadband with a speed of at least $2 \mathrm{Mbps}$, capability issues (through national campaigns to introduce basic IT skills to those who have not yet been online, such as RaceOnline 2012, and through plans to make digital channels the 'default' way of accessing some services and benefits [2].

Initiatives such as these may play a part in helping to narrow the digital divide, since the number of internet users, and particularly older users, has been growing steadily over recent years. In the UK for example, two million new users came online for the first time in 2010, of whom one million were over 55, and indeed the fastest growing group of internet users are those aged 75 and over. This group of users (who represent approximately $8 \%$ of the UK population) has increased from 15 per cent to 26 per cent between 2006 and 2011 [12]. However, such strategies focus primarily on the goal of getting people online in the first place. Emerging evidence suggests that there is another challenge to be addressed - that of sustaining digital engagement.

\section{Digital disengagement: a fourth digital divide?}

In 2004, the UK Government's Digital Inclusion Panel warned that there was a "real risk that in the medium to long term significantly more citizens will migrate from being digitally engaged to being unengaged than the other way round" because of changes in their capabilities as they age [10 p.79]. Triggered by this statement, and by personal knowledge of older people who had been regular internet users but whose usage had then declined - sometimes to the point of complete cessation the authors undertook a review of the literature and found that while there are many surveys of internet usage, only a few appear to have gathered data about 
discontinuation of use. The search included the Web of Knowledge database, the ACM Digital Library and Google Scholar. Boolean logic was used to combine search terms related to internet and synonyms for disuse, as shown in Table 1 below.

\section{TABLE 1 about here}

The studies that were found are summarised in Table 2 below. These studies show that some people who have used the internet at some point, and for some period of time, have subsequently stopped doing so. While some of these studies are quite dated, similar results are being found in the more recent studies, and analysis of the data from repeat surveys indicates that the percentages in the 'previous but not current' user category remain fairly consistent. The authors see this phenomenon as a potential but largely unrecognised 'fourth digital divide', i.e. it cannot be explained by a simple interpretation of lack of access, lack of skills or lack of interest or motivation, because the people in this category have formerly been users.

\section{TABLE 2 about here}

We suggest that the term 'digitally disengaged' is an appropriate term to describe such individuals. This is consistent with the use of the term disengagement by O'Brien and Toms (2008) [13], although their use of the term is specifically related to engagement in certain internet-based tasks and activities, rather than to overall usage of the internet. They define disengagement as occurring "when participants made an internal decision to stop the activity or when factors in the participants' external environment caused them to cease being engaged". 
The differences between the figures in these studies however suggest that there is a significant challenge in defining what it means to have discontinued using the internet, and consequently for quantification. The different surveys in Table 1 reveal a lack of consistency both in the terminology used and the indicators that have been used. For example, different surveys refer to different units of time in questions about how long has elapsed since the respondent last used the internet. In surveys carried out by National Opinion Polls (NOP) in the UK between 1995 and 1997 [14], respondents were asked if they had used the internet in the preceding month, and were categorised as 'lapsed' if they had not. Katz and Apsden [15, p.328] in a series of surveys in the US adopt the term 'dropouts' - defined as people who formerly used the internet at least once a month but no longer do. The biennial Oxford Internet Surveys (OIS) in the UK classify respondents variously as internet users, ex-users or non-users [6,7]. Ex-users are defined as those who have used the internet at least once in the past but have not done so in the previous three months. The Canadian census (figures for 2006 are reported in Young et al [16]) asks if respondents have used the internet in the past twelve months. Young et al. refer to such respondents as 'non-sustainers'.

The figures reported by Emmanouilides and Hammond are clearly anomalous in comparison to the other studies, and indeed the authors themselves acknowledge that the measure they adopted (people who have not used the internet in the past month) may simply be infrequent users rather than lapsed users [14]. Of course, whilst a longer period of time since last use might be regarded as evidence of lack of engagement, it may not signal complete discontinuation of usage.

Furthermore, few studies seem to have asked whether respondents who are not current users expect to become users again at some point in the future. The OIS is 
one exception; among ex-users in the 2009 study [7] 60 per cent reported that they would like to use the internet again in the future. This contrasts with only 19 per cent of non-users reporting that they would like to use the internet in future. The survey does not however capture data which could show whether such aspirations are realised.

\section{Factors underlying digital disengagement}

The surveys included in Table 2 also provide some understanding of the factors that underlie digital disengagement. Emmanouilides and Hammond [14] found that the most important factors associated with lapsed use were: time since first use (i.e. how long the respondent had been an internet user before the lapse - the longer the prior use, the lower the likelihood of lapsing); location of use (i.e. lapsing was less likely if usage was at home or work compared to public locations such as an internet café or school), and whether the internet was used alone or with other people (people who use the internet at home with two or more other people were more likely to be current users than those who used it alone or with one other person). The primary reasons for internet dropout revealed by Rice and Katz (2003) [17] were excessive complexity of the technology, and insufficient perceived relevance. Similar reasons are given by ex-users in the OIS 2011 survey [6]. To summarise, the key reasons for non-sustaining use reported in these studies include:

\footnotetext{
- disability

- $\quad$ complexity of the technology

- $\quad$ social isolation

- $\quad$ lower income

lower education
} 
- $\quad$ irrelevant/inappropriate content

\section{Digital disengagement and older people}

While published surveys of internet usage consistently show that those who have never used the internet are more likely to be old than young, the relationship between age and digital disengagement is not so clear-cut. Although Emmanouilides and Hammond [14] found that age did not have a statistically significant impact on continuity of use, the study by Young et al. [16] did find an association between age and non-sustained use of ICTs. They report that nonsustainers were slightly older, more likely to be male than female, and to have lower levels of income and education than current users.

The list of reasons for disengagement given above suggests that older people will be more vulnerable to the risk factors than younger people. Older people are more likely to develop one or more physical disabilities that could limit or curtail their use of computers and the internet such as visual problems, motor problems or musculoskeletal problems. Despite the availability of many aids to accessibility, people with a physical disability in any age group are much less likely than those without to be users of computers. Dutton and Blank [7] report consistent findings from the OIS studies in 2009 and 2011 that only around 41 per cent of disabled people use the internet, compared to 78 per cent of the non-disabled population. Young et al. [16] analysed Canadian census data relating to non-sustained use of the internet, and found that those who reported at least one activity limitation (defined by the Canadian census as a self-reported long-term physical or psychological health problem, or a chronic condition, that is severe enough to "often" affect normal functioning at home, at work, at school, or in another domain such as transportation 
or leisure activities) were more likely to be non-sustainers than those without such limitations (9.8 per cent compared to 3.5 per cent of the total population). Around half of these non-sustainers were over 60 years of age, and the most frequently reported cause of activity limitation was disease of the musculo-skeletal system and connective tissue.

Older people are also more likely than younger people to be socially isolated. They are also more likely to have lower incomes and to have reached lower educational levels [18]. Young et al. found that those on low income and living in rural communities were also over-represented in the group of non-sustainers [16]. They suggest that the challenges of having an activity limitation may lead to an enhanced drop-out rate for internet users when compounded by older age and a less supportive environment (e.g. loss of or separation from spouse or living in a rural setting).

Complexity of technology has implications for the capacity to sustain use since it relates to cognitive load and so may be more of an issue for older people, who are more likely to experience cognitive and mental health problems than younger people. A survey carried out by the UK's Office of National Statistics in 2000 found that "one sixth of those aged 60 to 64 , rising to one quarter of those aged 70 to 74 , were relatively impaired in standard tests of memory and concentration " [18]. There is evidence from several studies have shown that cognitive abilities are important predictors of both technology uptake and of technology usage [19].

The data presented in Table 2 above, albeit limited, suggest that there is evidence for a fourth digital divide, and that it may affect significant numbers of people. Perhaps the most compelling way to illustrate the potential scale of disengagement is to extrapolate from the most conservative figures i.e. those reported in Young et 
al. [16]. If 3.5 per cent of the total number of presumed current internet users in the UK in 2011 (85 per cent of the population, i.e. around 53 million people) had not used the internet for more than 12 months, this would equate to 1.85 million people who are actually no longer current users the internet and are thus not able to access the benefits and services that it provides.

\section{Sustaining digital engagement by older people}

The findings above provide the background to a large collaborative research project (Sus-IT: sustaining IT use by older people to promote autonomy and independence). This project was funded by the UK Research Councils' New Dynamics of Ageing research programme (http://www.newdynamics.group.shef.ac.uk/) and involves academic partners from 8 UK universities, led by the authors at Loughborough University [20]. This research is seeking to investigate further the phenomenon of digital disengagement specifically by older people, with a particular view to understanding the risk factors and how these might be mitigated, in order to help older users to sustain engagement and reduce the possibility of disengagement.

As part of this research project five case studies were carried out of older people who had been computer users but who reported that they had given up, in order to explore the factors which had led to disengagement,. The participants were an opportunity sample recruited from the local community and from an organisation which provides IT support services to older and disabled people. Data were collected by semi-structured interviews, which explored participant's health, social circumstances, the technology used, their motivations for using computers, and their 
training/support for computer use. The key findings are summarised in Table 3 below.

\section{Table 3 about here}

These case studies provide an insight into the complexity of the circumstances surrounding disengagement. In all of the cases, there was no single factor that led to disengagement, rather it was the result of a combination of factors and often following a gradual process of increasingly intermittent usage. For P1, for example, disengagement was due to a combination of very poor eyesight (caused by agerelated macular degeneration), coupled with a' broken' computer. Until the computer had broken, this participant had used it less and less frequently because of his visual impairment, but then gave up completely (a new replacement computer purchased by his children was never used). P2 was fearful of using the internet because of the possibility of identity theft or encountering inappropriate materials. Her initial motivation to use a computer was to write up her memoirs and once she had completed that task, she felt had 'run out' of things to do and gave her computer away. The cases also highlight the important and different roles that other people play. In the case of $\mathrm{P} 3$, for example, her primary motivation to use the internet was to communicate with her family, especially her brother, and after he died she had few other contacts to make sustained use worthwhile. For P4, by contrast, her husband was a keen user and since she did not enjoy using the computer and suffered physical problems when doing so, she was content to give it up and leave it to him. P5 had started to use a computer at the suggestion of his care agency, to increase 
his independence and well-being, but after a protracted period of ill-health including spells in hospital, he felt he had lost the skills and discontinued his usage.

\section{Conclusions and future directions}

The quantitative and qualitative studies reported above indicate that digital disengagement does occur and suggest some of the contributing factors. The case studies reported here also suggest that there is no single 'solution' that could have prevented disengagement for these individuals. Further research and engagement with a diverse group of more than 1000 older people in the UK is now being undertaken by the Sus-IT researchers to learn more about the benefits, challenges and difficulties that older people experience with using computers and the internet, to gain greater understanding of the risk factors and triggers for digital disengagement, and to identify potential solutions and mitigating strategies that they would find useful to resolve the problems encountered. The emerging findings from the Sus-IT project (to be published) suggest that a range of sociotechnical solutions are likely to be needed. Improvements in technology design and accessibility may help to alleviate problems of usage associated with health and impairment, but information and support must also be readily available to help older people to discover, choose and implement appropriate technical solutions for their needs.

Furthermore, the authors argue that current initiatives and strategies to close the 'digital divide' will not resolve or prevent the problem of disengagement. The global technology company IBM recently predicted (December 2011) that the digital divide will cease to exist in five years' time, "due to the advent of mobile technology" [21]. The evidence reviewed here relating to the factors that underlie disengagement gives no reason to hope that the advent of mobile technologies would have 
prevented this phenomenon. Equally, other initiatives designed to get people online through the provision of access and skills would not have resolved the problems experienced by the case study participants

In the UK we are currently at a crossroads in defining the nature of our future digital society. Significant strategy and policy decisions are in the making. Failure to recognise the 'fourth digital divide' may lead policy makers and commercial organisations to over-estimate the number of people who can access online services, and to under-estimate the need for alternative delivery channels and support. Existing statistical data are insufficient to determine the real scale of the phenomenon, but even if small percentages are involved, the implications for achieving both the economic and social benefits of widespread use of computers and internet-enabled services are potentially serious. It is clear that further research is needed to understand this complex phenomenon, if Governments and other agencies are to invest significant resources in alleviating or preventing it. Elements of a future research agenda are discussed below.

\section{i) Development of indicators of disengagement}

Robust and reliable evidence of the nature and scale of digital disengagement requires a systematic and widespread approach to collecting data. However a fundamental pre-requisite for this is to develop appropriate and sensitive indicators of disengagement. In few cases is it likely to be as clear-cut as in the cases of P2 and P3 above, who gave away their computers. Drawing conclusions based on the time interval since last use is problematic, since even after a prolonged period of disuse, there may be an intention to return to use at some future point. This also 
means that simple, direct questions such as 'Have you given up using your computer?' do not yield useful responses.

\section{ii) Longitudinal studies}

Equally there is little evidence at present about whether people who have been identified as non-sustainers do re-engage at some future point. It has been suggested [ [ 1 1] that older people are less likely than younger non-sustainers to reengage after a period of disengagement or disuse, perhaps because the factors that cause them to disengage are less likely to improve or disappear over time. Longitudinal studies are needed to explore this hypothesis.

\section{iii) Modelling disengagement}

The authors' analysis of the disengagement process has identified that multiple and interacting factors (physical, psychological, social and technological) are involved. Each of these aspects merits further research to gain knowledge and understanding of the triggers, onset and progression of contributory factors to disengagement and in particular the way in which the factors act cumulatively or in combination to reduce and potentially to bring to an end the digital engagement of individuals. 
Acknowledgements: The authors would like to acknowledge the contribution of Jatinder Sandhu, Research Associate on the Sus-IT research project, to the material presented in this paper. The Sus-IT research project (Sustaining digital engagement by older people to promote autonomy and independence) has been supported by a grant from the New Dynamics of Ageing (NDA) programme, funded by the five UK Research Councils - AHRC, BBSRC, EPSRC, ESRC and MRC (grant no. RES-35325-0008). Further details about the Sus-IT project are available at: http://www.susit.lboro.ac.uk/ 


\section{References:}

1. 3 Bradshaw H M: Digital Inclusion: Economic and social benefits for individuals and wider society. Social research report No. 26/2011 produced for the Welsh Government. Available from:

http://wales.gov.uk/topics/housingandcommunity/research/community/econsocial/ ?lang=en [accessed 01.02.13]

2. 10 UK Cabinet Office: Government Digital Strategy 2012. Available from: http://publications.cabinetoffice.gov.uk/digital/ [accessed 01.02.13]

3. 2 United Nations (UN): World population aging 1950-2050. New York: United Nations, Department of Economic and Social Affairs; 2006.

4. Turner K: Telehealth and Telecare for older people. Scottish Policy Now, Issue 2, March 2012 [accessed 01.06.13]

5. 1 Wangberg S C, Andreassen H K, Prokosch H-U, Vagos Santana S M, SørensenT, Chronaki CE: Relations between Internet use, socio-economic status (SES), social support and subjective health. 2007. Health Promot. Int. 23:1, 70-77

6. Dutton W H, Helsper E J, Gerber M M: The Internet in Britain. Oxford Internet Survey 2009 Report. Oxford: Oxford Internet Institute, University of Oxford; 2009.

7. Dutton W H, Blank G: Next Generation Users, The Internet in Britain. Oxford Internet Survey 2011. Oxford: Oxford Internet Institute, University of Oxford; 2011.

8. Internet World Stats Usage and Population Statistics. Available from: www.internetworldstats.com [accessed 01.02.13]

9. Norris P: Digital divide, Civic engagement, information poverty, and the Internet worldwide. Cambridge, England: Cambridge University Press; 2001.

10. UK Cabinet Office :Enabling a digitally United Kingdom. 2004. Available from http://webarchive.nationalarchives.gov.uk/+/http://www.cabinetoffice.gov.uk/media /cabinetoffice/corp/assets/publications/reports/digital/digitalframe.pdf [accessed 01.02.13]

11. Olphert C W, Damodaran L, May A: Towards digital inclusion - engaging older people in the digital world. Proceedings of the Conference for Accessible Design in the Digital World; August 2005. Available from: http://www.bcs.org/upload/pdf/ewic ad05 s7paper1.pdf [accessed 01.02.13] 
12. Ofcom: Communications Market Report, UK. [Internet]. 2010. London: Ofcom. Available from:

http://stakeholders.ofcom.org.uk/binaries/research/cmr/cmr11/UK CMR 2011 FI NAL.pdf

13. O Brien H L, Toms E G: What is user engagement? A conceptual framework for defining user engagement with technology. Jour Amer Soc Info Sci Tec 2008, 59(6): 938-955.

14. Emmanouilides C, Hammond K: Internet usage, predictors of active users and frequency of use. Journal of Interactive Marketing 2000, 24(2): 17-32.

15. Katz J E, Apsden P: Internet dropouts in the USA, the invisible group. Telecommunications Policy 1998; 22: 327-339.

16. Young W, Clarke J, Klima G, Gadag V, Gien L, \& Hardill I: Sustaining information and communication technology use among Canadians with at least one activity limitation. Int Jour Tech, Know Soci 2012, 7: 1-10.

17. Rice R E, Katz J E: Comparing internet and mobile phone usage: digital divides of usage, adoption and dropouts. Tele Pol 2003, 27: 597-623.

18. UK Office for National Statistics (ONS): Older People. Available from: http://www.statistics.gov.uk/hub/population/ageing/older-people [accessed 01.02.113]

19. Czaja S J, Lee C C: The impact of aging on access to technology. Univ Access Inf Soc 2007, 5:341-349.

20. Damodaran L \& Olphert C W: Sustaining digital engagement: some emerging issues. Proc. Digital Futures 10, Nottingham, UK. 10-12 October 2010 Available from:https://www.horizon.ac.uk/images/stories/f50-Damodaran.pdf [accessed 01.02.13]

21. IBM (2011). Five in five predictions 2011. Available from: http://www03.ibm.com/press/us/en/presskit/36223.wss [accessed 01.02.13] 
Table 1: Terms used for the literature search

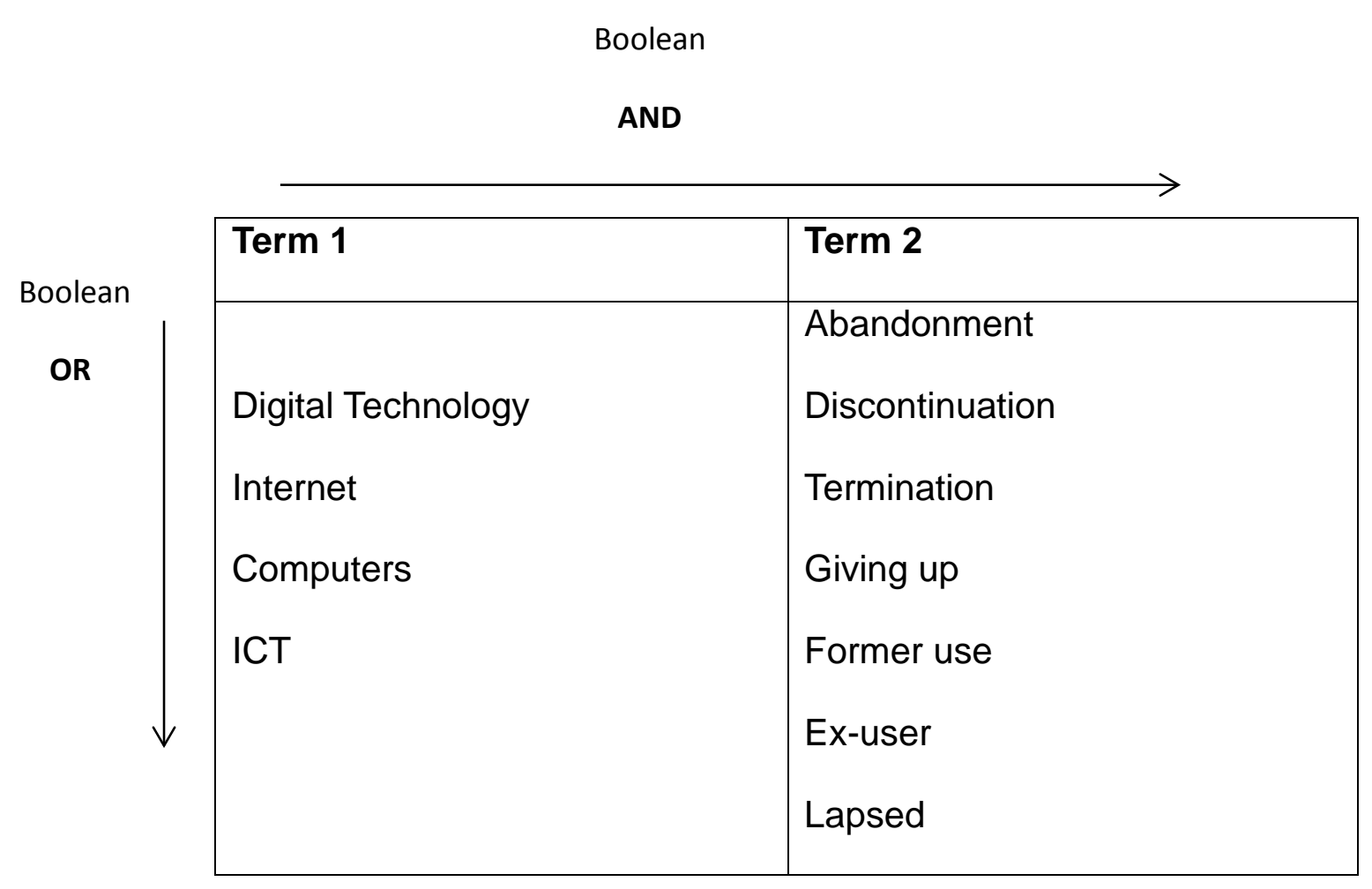


Table 2: Comparative results of surveys reporting former internet use rates

\begin{tabular}{|c|c|c|c|}
\hline Study & $\begin{array}{l}\text { Sample } \\
\text { size/location }\end{array}$ & Indicator & $\begin{array}{l}\text { Reported rate } \\
\text { per cent }\end{array}$ \\
\hline $\begin{array}{l}\text { Katz and Apsden 1996, } \\
1997,2000 \text { (reported in } \\
\text { Rice and Katz } 2003 \text { [15]) }\end{array}$ & $1305 /$ USA & $\begin{array}{l}\text { Had used } \\
\text { internet at } \\
\text { least once a } \\
\text { month but no } \\
\text { longer do }\end{array}$ & $\begin{array}{l}9.5 \text { per cent } \\
\text { (average across } 3 \\
\text { surveys) }\end{array}$ \\
\hline $\begin{array}{l}\text { NOP Surveys Dec } 1995 \text {, } \\
\text { June 1996, Dec } 1996 \text { and } \\
\text { June 1997) (reported in } \\
\text { Emmanouilides and } \\
\text { Hammond } 2000[14])\end{array}$ & $\begin{array}{l}943 \text { (average } \\
\text { across } 4 \\
\text { surveys)/UK }\end{array}$ & $\begin{array}{l}\text { Had not used } \\
\text { internet in } \\
\text { preceding } \\
\text { month }\end{array}$ & $\begin{array}{l}39 \text { per cent } \\
\text { (average across } 4 \\
\text { surveys) }\end{array}$ \\
\hline $\begin{array}{l}\text { Oxford Internet Surveys } \\
\text { 2003-2009 (reported in } \\
\text { Dutton and Blank } 2011 \\
\text { [7]) }\end{array}$ & $\begin{array}{l}2013 \text { (average } \\
\text { across } 4 \\
\text { surveys)/UK }\end{array}$ & $\begin{array}{l}\text { Had not used } \\
\text { the internet in } \\
\text { the preceding } \\
3 \text { months }\end{array}$ & $\begin{array}{l}7 \text { per cent } \\
\text { (average across } 4 \\
\text { surveys) }\end{array}$ \\
\hline $\begin{array}{l}\text { Canadian census } \\
\text { statistics } 2006 \text { (reported } \\
\text { in Young et al. } 2011 \text { [16]) }\end{array}$ & $\begin{array}{l}25,169,820 \\
\text { (total population) } \\
4,161,820 \\
\text { (population with } \\
\text { at least one } \\
\text { activity } \\
\text { limitation)/Canada }\end{array}$ & $\begin{array}{l}\text { Had not used } \\
\text { the internet in } \\
\text { the preceding } \\
12 \text { months }\end{array}$ & $\begin{array}{l}3.5 \text { per cent } \\
\text { (total population) } \\
9.8 \text { per cent } \\
\text { (of those with at } \\
\text { least one activity } \\
\text { limitation) }\end{array}$ \\
\hline
\end{tabular}


Table 3: Summary data from case studies of disengagement

\begin{tabular}{|c|c|c|c|c|c|c|c|c|c|c|}
\hline & Age & $M / F$ & Technology & Training & $\begin{array}{l}\text { Duration of } \\
\text { computer } \\
\text { use }\end{array}$ & $\begin{array}{l}\text { Motivation/main } \\
\text { purpose of use }\end{array}$ & Health/Disability & $\begin{array}{l}\text { Social } \\
\text { support }\end{array}$ & Indicator & $\begin{array}{l}\text { Reasons for } \\
\text { disengagement }\end{array}$ \\
\hline P1 & 88 & $M$ & $\begin{array}{l}\text { Computer and } \\
\text { internet; }\end{array}$ & $\begin{array}{l}\text { Some formal } \\
\text { training }\end{array}$ & $15+$ years & $\begin{array}{l}\text { Hobby } \\
\text { (photography), } \\
\text { social contact }\end{array}$ & $\begin{array}{l}\text { Macular } \\
\text { degeneration; } \\
\text { hearing } \\
\text { impairment }\end{array}$ & $\begin{array}{l}\text { Widower } \\
\text { living } \\
\text { alone, } \\
\text { family } \\
\text { support }\end{array}$ & $\begin{array}{l}\text { Self } \\
\text { reported } \\
\text { given up }\end{array}$ & $\begin{array}{l}\text { Eyesight } \\
\text { problems; } \\
\text { broken computer }\end{array}$ \\
\hline P2 & 88 & $\mathrm{~F}$ & $\begin{array}{l}\text { Computer/lap } \\
\text { top/ } \\
\text { Nintendo; no } \\
\text { internet use }\end{array}$ & $\begin{array}{l}\text { Some formal } \\
\text { training; one } \\
\text { to one } \\
\text { teaching }\end{array}$ & $10+$ years & $\begin{array}{l}\text { Hobby (writing), } \\
\text { learning a new } \\
\text { skill; no interest in } \\
\text { internet }\end{array}$ & $\begin{array}{l}\text { Macular } \\
\text { degeneration; } \\
\text { frozen shoulder; } \\
\text { mild cognitive } \\
\text { impairment }\end{array}$ & $\begin{array}{l}\text { Widowed, } \\
\text { support } \\
\text { from } \\
\text { agency }\end{array}$ & $\begin{array}{l}\text { Gave } \\
\text { away } \\
\text { computer }\end{array}$ & $\begin{array}{l}\text { Had achieved } \\
\text { main goal; no } \\
\text { interest in using } \\
\text { the internet }\end{array}$ \\
\hline P3 & 85 & $\mathrm{~F}$ & $\begin{array}{l}\text { Computer and } \\
\text { internet }\end{array}$ & $\begin{array}{l}\text { One to one } \\
\text { teaching }\end{array}$ & $\begin{array}{l}5 \text { years } \\
\text { approx }\end{array}$ & $\begin{array}{l}\text { Communication } \\
\text { (brother died, no- } \\
\text { one else to } \\
\text { communicate } \\
\text { with }\end{array}$ & $\begin{array}{l}\text { Ill-health; mobility } \\
\text { impairment; } \\
\text { anxiety }\end{array}$ & $\begin{array}{l}\text { Widowed; } \\
\text { support } \\
\text { from } \\
\text { agency }\end{array}$ & $\begin{array}{l}\text { Gave } \\
\text { away } \\
\text { computer }\end{array}$ & $\begin{array}{l}\text { No-one to } \\
\text { communicate } \\
\text { with }\end{array}$ \\
\hline P4 & 75 & $\mathrm{~F}$ & $\begin{array}{l}\text { Laptop and } \\
\text { internet }\end{array}$ & No training & Limited & $\begin{array}{l}\text { To have a go; to } \\
\text { move with the } \\
\text { times; no } \\
\text { sustained need }\end{array}$ & $\begin{array}{l}\text { Pain and dizziness } \\
\text { when using } \\
\text { computer }\end{array}$ & $\begin{array}{l}\text { Married; } \\
\text { husband as } \\
\text { user }\end{array}$ & $\begin{array}{l}\text { Self } \\
\text { reported } \\
\text { given up }\end{array}$ & $\begin{array}{l}\text { No sustained } \\
\text { need (husband } \\
\text { continued to use) }\end{array}$ \\
\hline P5 & 65 & $M$ & $\begin{array}{l}\text { Computer and } \\
\text { internet }\end{array}$ & $\begin{array}{l}\text { One to one } \\
\text { teaching }\end{array}$ & 9 years & $\begin{array}{l}\text { To increase } \\
\text { independence } \\
\text { and well-being } \\
\text { (prompted by } \\
\text { Social Services) }\end{array}$ & $\begin{array}{l}\text { Ill-health; mobility } \\
\text { impairment }\end{array}$ & $\begin{array}{l}\text { Married, } \\
\text { Support } \\
\text { from } \\
\text { agency }\end{array}$ & $\begin{array}{l}\text { Self } \\
\text { reported } \\
\text { given up }\end{array}$ & $\begin{array}{l}\text { Lost motivation } \\
\text { and forgot skills } \\
\text { through ill-health }\end{array}$ \\
\hline
\end{tabular}


